\title{
PENERAPAN PEMBELAJARAN BERBASIS SOCIO SCIENTIFIC ISSUES UNTUK MENINGKATKAN KEMAMPUAN ARGUMENTASI ILMIAH
}

\author{
Siska, Wili Triani, Yunita, Yuyun Maryuningsih, dan Mujib Ubaidillah \\ IAIN Syekh Nurjati Cirebon \\ e-mail: siskatariko@gmail.com
}

\begin{abstract}
Abstrak
Tujuan penelitian ini adalah menganalisis kemampuan argumentasi ilmiah siswa pada pembelajaran biologi dengan socio scientific issues. Penelitian ini dilakukan di dua sekolah yaitu SMA N 1 Suranenggala dan SMA N 1 Sliyeg yang terdapat di provinsi Jawa Barat. Penelitian ini menggunakan pretest-posttest control group design. Pengumpulan data pada penelitian ini menggunakan instrument tes berupa pretes dan postes, tes yang digunakan berupa tes uraian (essay) untuk mendapatkan data kemampuan argumentasi ilmiah siswa pada materi pembelajaran biologi yang berkaitan dengan isu-isu sosial yang marak terjadi di masyarakat. Data diambil dengan sampel menggunakan uji statistik meliputi uji prasyarat dan uji hipotesis menggunakan uji t.Hasil penelitian menunjukan bahwa terdapat peningkatan kemampuan argumentasi ilmiah siswa menggunakan strategi pembelajaran socio scientific issues.
\end{abstract}

Keywords: Socio Scientific Issues, Argumentasi IImiah, Pembelajaran Biologi

\begin{abstract}
This study aimed to analyze the students' scientific argumentation abilities in biology learning through socio-scientific issues. This study was conducted in two schools; Senior High School of Suranenggala 1 and Senior High School of Sliyeg 1 which is located in West Java Province. This study uses a pretest-posttest control group design. The data collection in this study used pretest and posttest as the instruments. the test used is in form of a descriptive test (essay) to obtain data on students' scientific argumentation abilities on biology learning material related to social issues in society. The data were taken by sample using statistical tests including prerequisite tests and hypothesis testing using t-tests. The results of the study showed that there was an increase in students' scientific argumentation abilities using socio scientific issues learning strategies.
\end{abstract}

Keywords: Socio Scientific Issues, Scientific Arguments, Biology Education

\section{PENDAHULUAN}

Argumentasi menjadi hal utama untuk melandasi peserta didik dalam belajar bagaimana menghasilkan suatu bukti, menguji, dan mengevaluasi teori, dan berkomunikasi (Osborn, 2004). Argumentasi memainkan peran penting dalam mengembangkan pola berpikir kritis dan menambah pemahaman yang mendalam terhadap suatu gagasan maupun ide (Song dan Deane, 2014). Argumentasi penting dikembangkan dalam pembelajaran biologi karena mampu meningkatkan pemikiran untuk menguji pemahaman peserta didik. Ada tiga alasan pentingnya argumentasi dalam 
pembelajaran; (1) ilmuwan menggunakan argumentasi dalam mengembangkan dan meningkatkan pengetahuan ilmiahnya, (2) masyarakat menggunakan argumentasi dalam perdebatan ilmiah, dan (3) para peserta didik dalam pembelajaran membutuhkan argumentasi untuk memperkuat pemahamannya (Erduran, 2005). Pada kenyataannya masih banyak ditemui peserta didik yang mengalami kesulitan dalam hal ini sehingga pembelajaran harus mulai diarahkan untuk melibatkan para peserta didik dalam argumentasi ilmiah sebagai bagian dari sains. Hal ini kemampuan menganalisis dan kemampuan argumentasi peserta didik rendah. Berdasarkan hasil penelitian Sandoval (2005) menunjukkan bahwa peserta didik SMA di negara maju mengalami kesulitan dalam membuat argumen ilmiah, kesulitan yang dirasakan dalam menjelaskan gejala sains secara empiris dalam diskusi kelas.

Keterampilan argumentasi ilmiah peserta didik yang masih rendah berkaitan dengan kurangnya pengalaman belajar peserta didik dan dominasi guru dalam proses pembelajaran menyebabkan pemahaman peserta didik terhadap materi kurang, hal ini menyebabkan kemampuan menganalisis rendah sehingga kemampuan argumentasi ilmiah (scientific argumentation) tidak berkembang (Newton dan Osborne, 2000; Erduran, 2006). Salah satu upaya untuk meningkatan kemampuan argumentasi peserta didik adalah dengan menerapkan pendekatan pembelajaran SSI (socio scientific issues), pendekatan ini mengandung aspek-aspek sosial yang marak terjadi dan harus dipelajari oleh peserta didik. Argumentasi memainkan peran penting dalam mengembangkan pola berpikir dan menambah pemahaman yang mendalam terhadap suatu gagasan maupun ide bagian utama dalam proses pembelajaran adalah belajar terlibat dalam berbagai aspek penting meliputi merumuskan pertanyaan, mendeskripsikan mekanisme, dan membangun argumen sehingga argumentasi melatih peserta didik dalam menggunakan kemampuan berpikirnya, dapat membangun pemahaman konsep. (Amining, 2018; Zeidler, 2005).

Pendekatan socio scientific issue merupakan salah satu pendekatan dalam proses pembelajaran yang menuntut peserta didik untuk berperan lebih aktif. Pendekatan ini hampir sama dengan pendekatan berbasis masalah, dimana proses pembelajaran dilakukan melalui pengenalan masalah-masalah yang kontekstual (Anagun, 2010), perbedaannya hanya terletak bagaimana masalah tersebut dikembangkan. Dalam pendekatan berbasis masalah, masalah tersebut sudah disajikan dalam bentuk pertanyaan oleh gurusedangkan dalam pendekatan sosio-saintifik masalah-masalah harus dikembangkan sendiri oleh peserta didik dengan mengembangkan berbagai aspek, baik dari aspek sains itu sendiri, moral, ekonomi, dan lain-lain.

Permasalahan atau isu-isu sosial yang dapat diangkat dengan menggunakan sosio-saintifik harus memiliki beberapa kriteria (Ratcliffe, 2003), yaitu: 1) Mempunyai dasar sains, 2) melibatkan pembentukan opini, membuat pilihan pada tingkat individu maupun 
masyarakat, 3) sering disorot oleh media, 4) terdapat kekuranglengkapan informasi, 5) mengarah pada dimensi lokal, nasional, dan global yang berkaitan dengan kerangka politik dan sosial, 6) melibatkan nilai-nilai dan pertimbangan etis, 7) memerlukan pemahaman tentang berbagai kemungkinan dan resikoopik berkaitan dengan kejadian dilingkungan sekitar sehingga socio scientific issues sangat bagus ketika diterapkan didalam pembelajaran sehingga dapat menambah argumentasi peserta didik dalam pembelajaran dengan bertujuan untuk mengembangkan keefektifan peserta didik dalam mempelajari masalah sains.

Pembelajaran SSI mengefektifkan pembelajaran pada aspek-aspek kehidupan sehari-hari dengan isu-isu sains pro dan kontra dan isu-isu sosial di lingkungan masyarakat, sehingga pembelajaran SSI ini memiliki rasa keingintahuan peserta didik mngenai isu-isu kontroversial dalam kehidupan sehari-hari. Pembelajaran berbasis SSI dapat mengembangkan cara berpikir kritis mahapeserta didik terhadap suatu isu atau masalah yang dihadapi dalam dunia nyata ( Andryani, 2016; Mazfufah, 2015).

SSI merupakan proses pembelajaran yang menyediakan situasi belajar begitu bermakna bagi peserta didik agar dapat mengaplikasikan pengetahuan biologinya pada suasana sosial di dalam kelas. Tantangan untuk saling berbagi gagasan, pengetahuan, serta nilai-nilai yang berpijak pada isu-isu sosial yang disajikan dalam pembelajaran. Pembelajaran SSI merupakan proses pembelajaran yang dikaitkan dengan isu-isu sosial yang ada di lingkungan dan masyarakat yang berpotensi untuk mendukung pengembangan kemampuan intelektual, kemampuan berkomunikasi, sikap sosial, kepedulian dan partisipasi peserta didik. Pendekatan ini bertujuan untuk menstimulasi perkembangan intelektual, moral dan etika serta kesadaran perihal hubungan antara sains dengan kehidupan sosial (Zeidler, 2005; 2008).

Argumentasi ilmiah dalam sains mempunyai karakteristik yang khas dibanding dengan argumentasi dalam konteks sehari-hari atau dalam bidang ilmu lain, terutama dalam keterkaitan antara pernyataan (claim), bukti (evidence), dan pertimbangannya (Reasoning) (MC.Neil dan Krajick, 2006). Peserta didik yang membuat suatu claim diharapkan memberikan dukungan dengan menggunakan bukti-bukti dan alasan, mengandung fakta serta kondisi yang dapat diamati secara objektif, keyakinan atau pernyataan yang secara umum dapat diterima sebagai suatu kebenaran atau kesimpulan yang telah ditetapkan.

Kemampuan argumentasi ilmiah peserta didik di beberapa SMA wilayah III Cirebon masih tergolong rendah, hal ini berdasarkan hasil survey dan wawancara bersama guru mata pelajaran Biologi di SMA Wilayah 3 Cirebon masih menggunakan sistem Teacher Centre yang berarti pembelajaran masih berpusat pada guru, peserta didik kurang diberikan kesempatan untuk terlibat aktif dalam pembelajaran sehingga tidak 
berkembangnya kemampuan-kemampuan peserta didik salah satunya kemampuan argumentasi ilmiah, terlebih lagi di wilayah Kabupaten Cirebon bahwa sistem pembelajaran di SMA masih konvensional dan banyak peserta didik-siswi yang belum terbiasa menyampaikan argumentasi ilmiah dalam pembelajaran di kelas sehingga perlu diterapkan pembelajaran berbasis socio scientific issue.

\section{METODE}

Metode yang digunakan dalam penelitian ini adalah metode kuantitatif-deksriptif, dengan desain penelitian pretest-posttest control group. Populasi dalam penelitian ini berjumlah 340 peserta didik dengan sampel 140 peserta didik pada kelas XI MIPA di SMA Negeri 1 Suranenggala dan SMA Negeri 1 Sliyeg.

Pengumpulan data pada penelitian ini menggunakan instrument tes berupa pretes dan postes, tes yang digunakan berupa tes uraian (essay) untuk mendapatkan data kemampuan argumentasi ilmiah peserta didik pada materi pembelajaran biologi yang berkaitan dengan isu-isu sosial yang marak terjadi di masyarakat. Pembuatan soal berpedoman dengan aspek-aspek dari argumentasi ilmiah menurut MC.Neil dan Krajick (2006), data diambil dengan sampel menggunakan uji statistik meliputi uji prasyarat dan uji hipotesis menggunakan uji t.

\section{HASIL DAN PEMBAHASAN}

Peningkatan kemampuan argumentasi ilmiah peserta didik dapat diketahui melalui hasil pretest dan posttest pada masing-masing kelas baik secara umum maupun pada tiap aspek kemampuan argumentasi ilmiah. Berikut data perbandingan nilai rata-rata argumentasi ilmiah peserta didik yang diperoleh dari pretest dan posttest pada kelas yang diterapkan SSI dan kelas yang tidak diterapkan SSI pada sekolah SMAN 1 Suranenggala dan SMAN Sliyeg dapat dilihat pada Gambar 1.

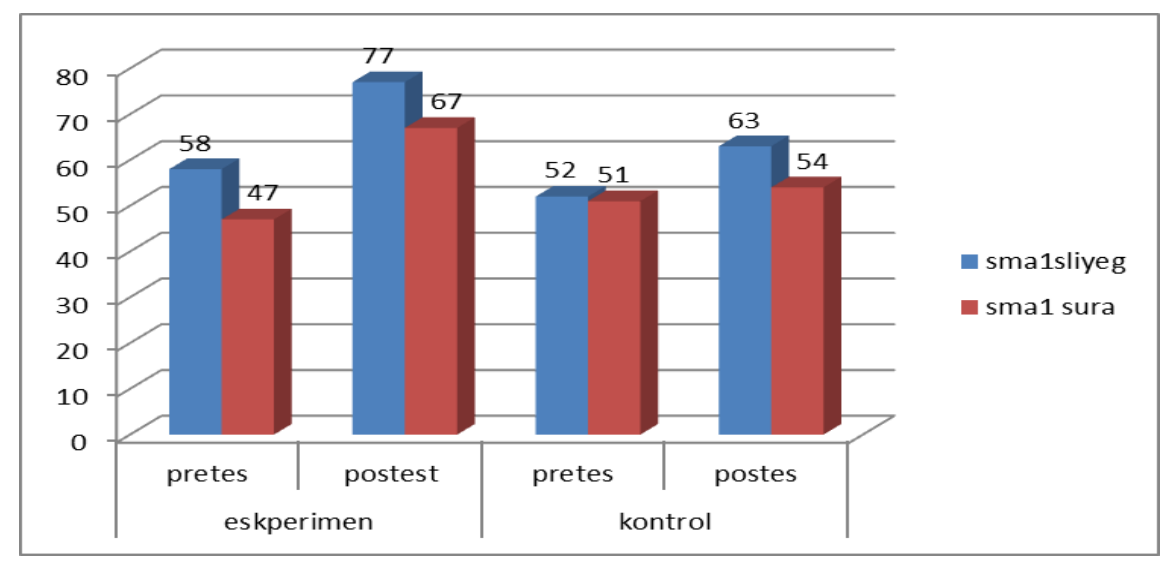

Gambar 1. Data Kemampuan Argumentasi IImiah Peserta didik 
Gambar 1 menunjukkan bahwa nilai rata-rata pretes kemampuan argumentasi ilmiah peserta didik di SMA N 1 Suranenggala pada kelas yang diterapkan SSI dan kelas yang tidak diterapkan SSI, dimana pada kelas yang tidak diterapkan SSI lebih besar dibandingkan dengan kelas yang diterapkan SSI. Kelas yang diterapkan SSI memperoleh nilai rata-rata sebesar 47 dengan kategori sedang sedangkan kelas yang tidak diterapkan SSI memperoleh nilai sebesar 51 dengan kategori sedang. Sedangkan pada posttest nilai rata-rata kemampuan argumentasi ilmiah peserta didik pada kelas yang diterapkan SSI dan kelas yang tidak diterapkan SSI mengalami peningkatan. Peningkatan yang diperoleh kelas yang diterapkan SSI lebih tinggi dibandingkan dengan kelas yang tidak diterapkan SSI, dimana kelas yang diterapkan SSI memperoleh nilai rata-rata kelas sebesar 67 deangan kategori tinggi, sedangkan kelas yang tidak diterapkan SSI mengalami peningkatan dengan nilai rata-rata kelas 54 dengan kategori sedang.

Presentase hasil peningkatan pada kelas yang diterapkan SSI memiliki peningkatan sebesar $19 \%$, sehingga dapat disimpulkan bahwa pada saat pemberian pretes, peserta didik belum bisa mengaitkan argumentasi mereka dengan teori ilmiah sistem reproduksi (evidence) sedangkan pada saat melakukan postes, peserta didik sudah mampu menjawab evidence(pengkaitan teori) karena peserta didik sudah mempelajari pembelajaran sistem reproduksi pada kegiatan pembelajaranya, sedangkan untuk penyimpulan reasoning peserta didik sudah bisa menjawab dengan baik dikarenakan peserta didik sudah mempelajari dengan kegiatan diskusi argumentasi ilmiah khususnya pada kelas yang diterapkan SSI. Presentase hasil peningkatan pada kelas yang tidak diterapkan SSI mempunyai nilai $11 \%$, sehingga dapat disimpulkan bahwa antara perbandingan kelas yang diterapkan SSI yakni mencapai peningkatan $8 \%$ lebih tinggi pada kelas yang diterapkan SSI sehingga terjadi peningkatan pada keduanya.

Perbedaan nilai rata-rata kemampuan argumentasi ilmiah peserta didik antara antara kelas yang diterapkan SSI dengan kelas yang tidak diterapkan SSI dapat diuraikan dan diamati lebih rinci pada Gambar 2. Berikut grafik nilai rata-rata pretest-posttest setiap indikator argumentasi ilmiah: 


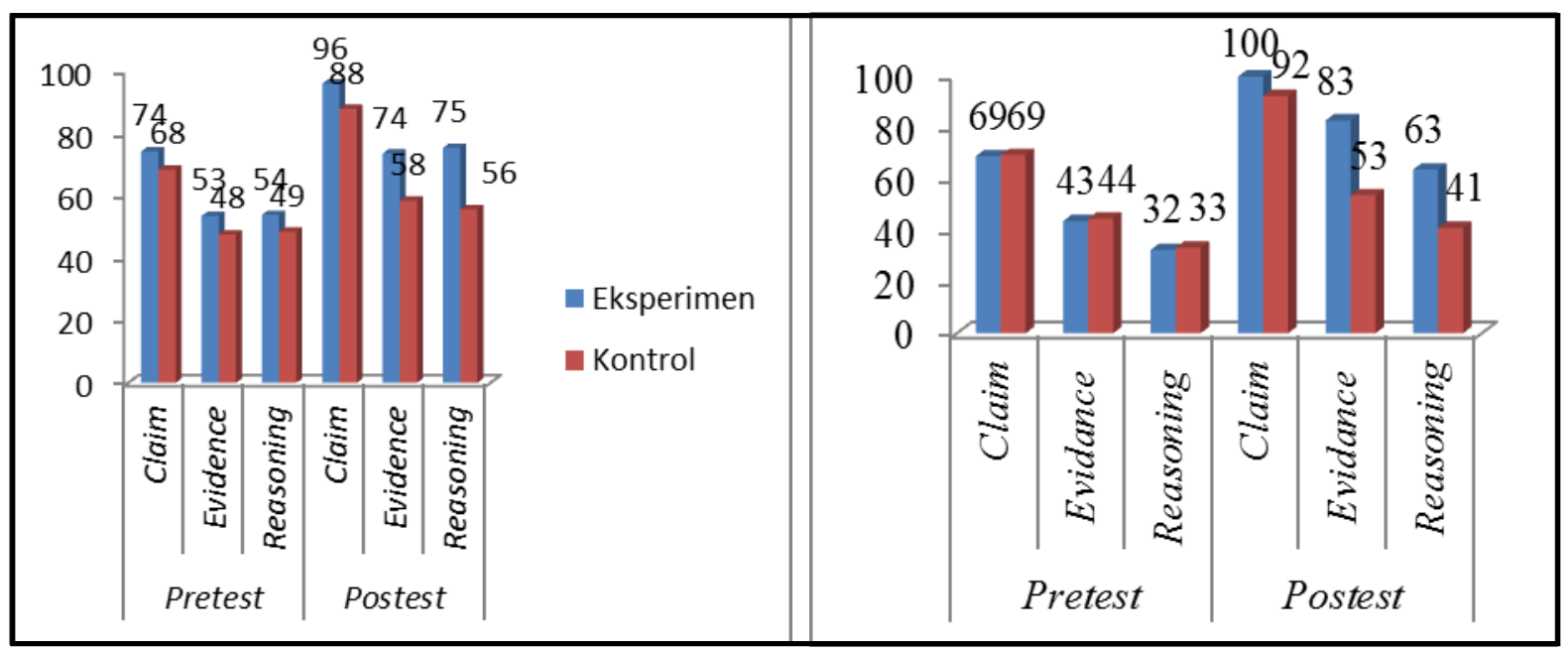

(a)

(b)

Gambar 2. (a) Kelas Eksperimen; (b) Kelas Kontrol

Gambar 2 menunjukkan pretest kelas yang tidak diterapkan SSI, indikator Claim memperoleh nilai rata-rata tertinggi, sedangkan nilai rata-rata Reasoning merupakan nilai pretest yang terendah. Dengan demikian nilai rata-rata pretest kelas yang tidak diterapkan SSI dapat dituliskan dengan Claim > Evidanve >Reasoning. Begitu pula, kelas yang diterapkan SSI nilai rata-rata pretest tertinggi terletak pada Claim sedangkan nilai rata-rata pretest terendah terdapat pada Reasoning. Sehingga dapat disimpulkan bahwa nilai ratarata pretest kelas yang diterapkan SSI untuk setiap aspek Argumentasi IImiah yaitu Claim $>$ Evidence $>$ Reasoning. Setelah mengikuti proses pembelajaran (Nilai posttest), terdapat peningkatan nilai posttest baik secara umum ataupun per indikator argumentasi ilmiah peserta didik. Sedangkan pada SMAN 1 Sliyeg, berdasarkan gambar 3 hasil menunjukan bahwa pretest kelas yang tidak diterapkan SSI, indikator Claim memperoleh nilai rata-rata tertinggi, sedangkan nilai rata-rata Reasoning merupakan nilai pretest yang terendah. Dengan demikian nilai rata-rata pretest kelas yang tidak diterapkan SSI dapat dituliskan dengan Claim $>$ Evidanve $>$ Reasoning. Begitu pula, kelas yang diterapkan SSI nilai ratarata pretest tertinggi terletak pada Claim sedangkan nilai rata-rata pretest terendah terdapat pada Reasoning. Sehingga dapat disimpulkan bahwa nilai rata-rata pretest kelas yang diterapkan SSI untuk setiap aspek Argumentasi IImiah yaitu Claim > Evidanve > Reasoning. Dan setelah mengikuti proses pembelajaran (Nilai posttest), terdapat peningkatan nilai posttest baik secara umum ataupun per indikator argumentasi ilmiah peserta didik

Aspek kemampuan argumentasi ilmiah menurut Mc.Neill dan Krajick (2006) meliputi Claim, Evidence, Reasoning dan Rebuttal. Berdasarkan hasil penelitian, aspek Claim memperoleh prosentase nilai rata-rata teringgi dibandingkan aspek lainnya. Menurut peneliti hal tersebut dikarenakan aspek Claim merupakan pengungkapan pernyataan terhadap satu permasalahan. Dimana peserta didik diharapkan untuk mampu 
mengungkapkan pernyatannya terhadap suatu isu atau suatu masalah, hal ini tidak akan terlalu sulit bagi peserta didik karena mengungkapkan pernyataan terhadap suatu isu dapat didasari oleh pengetahuan peserta didik itu sendiri dan dapat secara logika. selain itu Claim yang harus diberikan oleh peserta didik merupakan pernyataan atau Claim yang singkat. Tetapi peserta didik tidak dianjurkan untuk asal dalam memberikan pernyataannya, karena Claim yang mendasari Evidence dan Reasoning. Apabila Claim nya sudah salah, maka Evidence dan Reasoning pun belum tentu benar. Menurut Fisher (2009) kemampuan argumentasi ilmiah khusunya Claim merupakan fondasi dari berpikir logis dan kritis yang melibatkan kemampuan mengemukaan pendapat dengan ditambahanya dalam argumentasi yaitu suatu alasan. Didukung oleh Keraf (2007) argumentasi ilmiah adalah pernyataan yang didukung oleh beberapa bukti atau fakta.

Aspek Evidence merupakan aspek kedua yang memperoleh prosentase tertinggi kedua setelah aspek Claim. Menurut peneliti hal tersebut dikarenakan aspek Evidence merupakan pemberian data ilmiah untuk mendukung suatu Claim. Dimana peserta didik diharuskan menyajikan data-data secara ilmiah baik dari teori-teori yang sudah mereka pelajari dalam pembelajaran maupun data ilmiah yang berasal dari yang peserta didik ketahui dari berbagai media bahkan praktikum.

Pengatahuan atau wawasan yang sedikit akan menyulitkan peserta didik dalam memberikan data ilmiah, bahkan pemahaman yang minim akan konsep biologi dalam pembelajaran pun dapat menyulitkan peserta didik dalam memberikan data ilmiah untuk mendukung suatu Claim. Khun (2010) menyatakan bahwa argumentasi seseorang tidak hanya berbentuk teori namun harus dibuktikan kebenarannya baik dengan memberikan contoh fakta nyata atau hasil penelitian dari para ahli.

Aspek Reasoning yang memperoleh persentase nilai rata-rata paling rendah. Hal ini dikeranakan menurut peneliti, peserta didik mampu memberikan argumentasinya secara tertulis namun tidak disertai dengan contoh-contoh fakta nya yang mendukung argumentasinya. Hasil penelitian ini mendukung penelitian Sandoval (2005) bahwa penelitian yang menunjukan bahwa peserta didik sering tidak menggunakan pembuktian yang cukup atau mencoba untuk membenarkan pernyataan mereka atau penggunaan bukti dalam argumentasi yang dihasilkan. aspek Reasoning merupakan suatu alasan atau pembenaran sebagai bukti yang dapat berupa contoh-contoh fakta maupun ilmiah yang sudah pernaterjadi maupun masih berbentuk teori. Dimana peserta didik diharuskan menyajikan alasan, contoh sebagai bukti yang membenarkan Claim dan Evidence diawal. Reasoning merupakan aspek yang penting karena Claim maupun evidence tidak dapat dibuktikan jika bukti tidak mampu disajikan. Hal ini akan sulit dilakukan oleh peserta didik jika peserta didik kurang menguasai konsep dan teori biologi dengan baik sehingga peserta didik tidak dapat memberikan bukti yang mendukung. Menurut Khun (2010) 
argumentasi tidak hanya dibatasi oleh teori namun peserta didik harus mampu membuktikan kebenarannya.

Aspek Rebuttal sebagai aspek tambahan yang dapat diukur dengan diskusi dan presentasi. Rebuttal adalah pernyataan sanggahan terhadap argumentasi atau penolakan terhadap argumentasi kelompok lain. Menurut Llewellyn (2013) berpendapat atau memberikan penolakan terhadap argumentasi kelompok lain merupakan proses dari diskusi.

Untuk mengetahui perbedaan nilai peningkatan argumentasi ilmiah nya, dapat dilakaukan dengan uji N-Gain. Berikut grafik N-Gain kemampuan Argumentasi Ilmiah antara kelas yang tidak diterapkan SSI dan yang diterapkan SSI secara umum di SMAN 1 Suranenggala dan SMAN 1 Sliyeg:

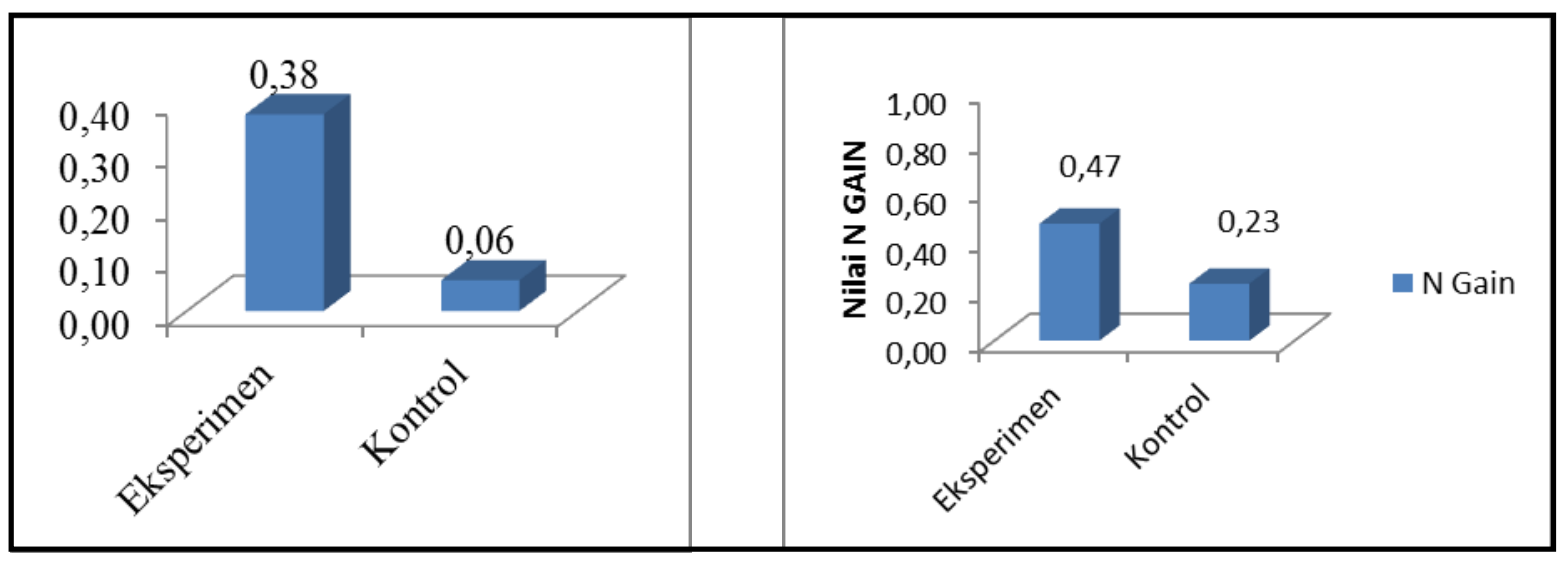

(a)

(b)

Gambar 3 (a) Kelas SSI; dan (b) Kelas non-SSI

Gambar 3 (a) menunjukkan kelas yang diterapkan SSI mengalami peningkatan kemampuan argumentasi ilmiah yang lebih tinggi dibandingkan dengan kelas yang tidak diterapkan SSI. Kelas yang diterapkan SSI memperoleh $N$-gain 0,38 dengan kategori nilai $\mathrm{N}$-gain sedang, sedangkan $\mathrm{N}$-gain kelas yang tidak diterapkan SSI hanya 0,06 dengan kategori nilai N-gain rendah. Gambar 3 (b) menunjukkan hasil analisis data N-Gain menunjukan bahwa peningkatan keterampilan argumentasi ilmiah peserta didik kelas yang diterapkan SSI dengan nilai N Gain sebesar 0,47 termasuk kedalam pengkategorian N Gain dengan nilai rendah sedangkan pada kelas yang tidak diterapkan SSI mempunyai nilai N Gain sebesar 0,23 termasuk pengkategorian N Gain dengan nilai rendah sehingga dapat disimpulkan bahwa terjadi perbedaan peningkatan yang signifikan antara kelas yang tidak diterapkan SSI dengan kelas yang diterapkan SSI. 
Tabel 1. Uji Hipotesis N-Gain Kelas Pendekatan SSI

\begin{tabular}{|c|c|c|c|}
\hline Data & Uji Hipotesis & Sig. & Ket. \\
\hline \multirow[t]{2}{*}{ N-Gain } & Mann Whitney & 0,000 & $\begin{array}{l}\text { Berbeda } \\
\text { signifikan }\end{array}$ \\
\hline & Independent sample test & 0,000 & $\begin{array}{l}\text { Berbeda } \\
\text { signifikan }\end{array}$ \\
\hline
\end{tabular}

Tabel 1 menunjukan hasil uji hipotesis menggunakan uji Mann Whitney data $\mathrm{N}$-gain menunjukan nilai signifikansi 0,000 yang bahwa Ho ditolak dan Ha diterima. sedangkan hasil uji hipotesis di SMAN 1 Sliyeg menggunakan uji Independent sample test dengan nilai sig sebesar 0,000 yang berarti bahwa Ho ditolak dan Ha diterima. Berdasarkan data tersebut dapat disimpulkan bahwa terdapat perbedaan peningkatan argumentasi ilmiah peserta didik yang signifikan.

Indikator keterampilan berargumentasi claim dan reasoning terdapat data yang tidak normal sehingga digunakan uji nonparametrik (mann-whitney test), sedangkan pada indicator evidance berdistribsi normal sehingga menggunakan uji independent sample test. hasil uji beda pada setiap keterampilan berargumentasi siwa dijelaskan pada Tabel 2.

Tabel 2. Hasil Uji Beda Tiap Indikator Keterampilan Berargumentasi

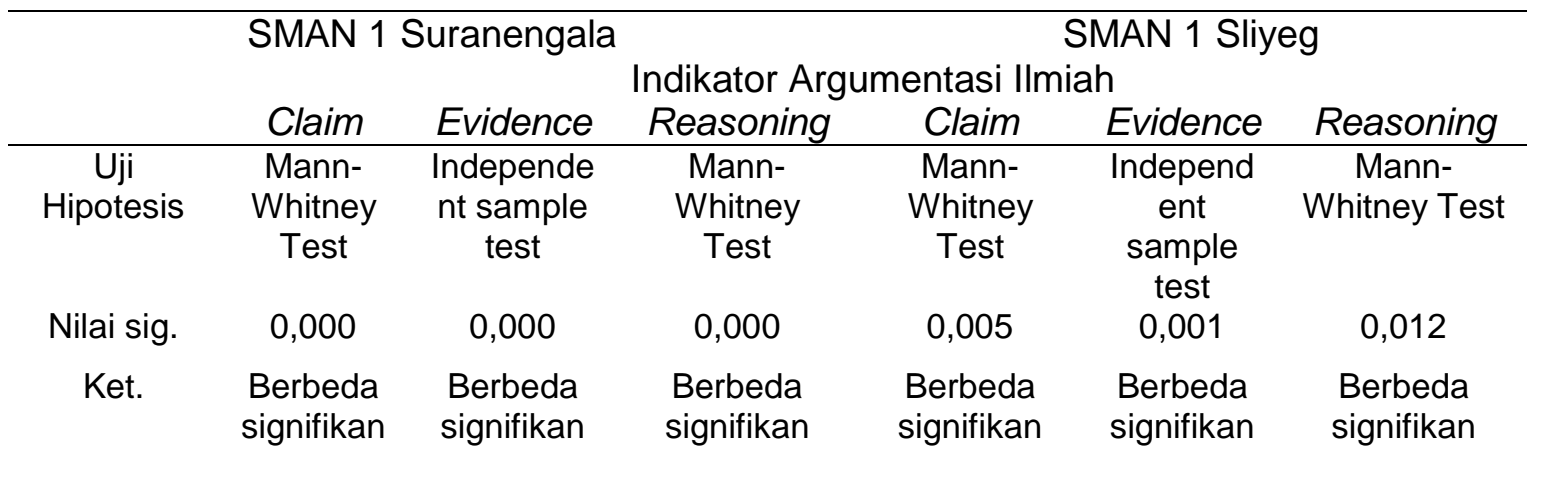

Hasil Uji t pada tabel 2 menunjukkan bahwa pada SMA N 1 Suranenggala pada kemampuan berargumentasi peserta didik pada indikator claim menggunakan uji mannwhitney test dengan nilai signifikan 0,000 lebih kecil dari 0,05 sehingga $\mathrm{N}$-gain yang diterapkan SSI dan N-gain yang tidak diterapkan SSI terdapat perbedaan yang signifikan. Berdasarkan rata-rata N-gain yang diterapkan SSI lebih besar dari rata-rata N-gain yang tidak diterapkan SSI, artinya kelas yang diterapkan SSI pada kemampuan berargumentasi peserta didik pada indikator claim lebih baik dari pada kelas yang tidak diterapkan SSI.

Kemampuan berargumentasi peserta didik pada indikator evidence menggunakan uji independent sample test dengan nilai signifikan 0,000 lebih kecil dari 0,05 sehingga $\mathrm{N}$ gain yang diterapkan SSI dan N-gain yang tidak diterapkan SSI terdapat perbedaan yang signifikan. Berdasarkan rata-rata N-gain yang diterapkan SSI lebih besar dari rata-rata N- 
gain control, artinya kelas yang diterapkan SSI pada kemampuan berargumentasi peserta didik pada indikator evidence lebih baik dari pada kelas yang tidak diterapkan SSI.

Kemampuan berargumentasi peserta didik pada indikator reasoning menggunakan mann whitney dengan nilai signifikan 0,000 lebih kecil dari 0,05 sehingga $\mathrm{N}$-gain yang diterapkan SSI dan N-gain yang tidak diterapkan SSI terdapat perbedaan yang signifikan. Berdasarkan rata-rata N-gain yang diterapkan SSI lebih besar dari rata-rata N-gain yang tidak diterapkan SSI, artinya kelas yang diterapkan SSI pada kemampuan berargumentasi peserta didik pada indikator reasoning lebih baik dari pada kelas yang tidak diterapkan SSI.

Hasil uji thitung pada SMA N 1 Sliyeg pada peningkatan argumentasi ilmiah pada indikator claim menggunakan uji mann-whitney test dengan nilai signifikan 0,005 lebih kecil dari 0,05 sehingga gain yang diterapkan SSI dan gain yang tidak diterapkan SSI terdapat perbedaan yang signifikan. berdasarkan rata-rata gain yang diterapkan SSI lebih besar dari rata-rata gain yang tidak diterapkan SSI artinya kelas yang diterapkan SSI pada keterampilan berargumentasipada indikator claim lebih baik dari pada kelas yang tidak diterapkan SSI.

Peningkatan argumentasi ilmiah pada indikator evidence menggunakan uji independent sample test dengan nilai signifikan 0,001 lebih kecil dari 0,05 sehingga gain yang diterapkan SSI dan gain yang tidak diterapkan SSI terdapat perbedaan yang signifikan. Berdasarkan rata-rata gain yang diterapkan SSI lebih besar dari rata-rata gain yang tidak diterapkan SSI, artinya kelas yang diterapkan SSI pada keterampilan berargumentasi peserta didik pada indicator evidence lebih baik dari pada kelas yang tidak diterapkan SSI.

Keterampilan berargumentasi ilmiah pada indikator reasoning menggunakan mann whitney dengan nilai signifikan 0,012 lebih kecil dari 0,05 sehingga gain yang diterapkan SSI dan N gain yang tidak diterapkan SSI terdapat perbedaan yang signifikan. berdasarkan rata-rata gain yang diterapkan SSI lebih besar dari rata-rata gain yang tidak diterapkan SSI. artinya kelas yang diterapkan SSI pada keterampilan berargumentasi peserta didik pada inkator reasoning lebih baik dari pada kelas yang tidak diterapkan SSI.

\section{SIMPULAN}

Pendekatan Sosioscientific Issue dapat meningkatkan argumentasi ilmiah peserta didik karena pada proses pembelajaran dengan pendekatan sosio scientific issue, peserta didik disajikan isu dari sudut pandang pengetahuan sains (scientific background). Selain itu, peserta didik diharuskan untuk mengevaluasi isu sosial sains yang disajikan (evaluation of information), mengkaji dampaknya secara lokal, nasional dan global (local, 
national, and global dimension), dan membuat keputusan terkait isu sosial sains tersebut (decision making).

\section{DAFTAR PUSTAKA}

Anagun, Sengul. \& M.Ozden. 2010. Teacher Candidate Prespection Regarding Sosiocientific Issue and Their Competeins in Using Sosiocientific Issue in Science and Technology Instruction. Journal of Procedia Sosial and behaviorial science, 9(2): 981-983

Andryani. Fitrian. 2016. Penerapan Pendekatan SSI (Socio Scientifici Issues) dengan Menggunakan Edia Power Point Terhadap Kekemampuan Berpikir Kritis Pada Mahasiswa Baru Angkatan 2015. Jurusan Pendidikan Fisiska Fakultas Tarbiyah Dan Keguruan Universitas Islam Negeri Alauddin Makasar. Skripsi. Universitas Islam Negeri Alauddin makasar. Makasar

Clark,D.B.\& Sampson,V.J. 2008. Assessing Dialogic Argumentation in Online Environments to Relate Structure, Grounds, And Conceptual Quality. Journal of Research in Science Teaching, 45 (3): 293-321.

Erduran, S., Simon, S, dan Osborne, J. 2006. Learning to Teach Argumentation: Research and Development in The Science Classroom. International Journal of Science Education, 28(2).

Erduran,S \& Orborne. 2005. The Role Of Argument in Developing Scienceliteracy. Research and Quality of Science Education. Nederlands: Spinger.

Fisher, Alec. 2009. Berpikir Kritis Sebuah Pengantar. Jakarta: Erlangga.

Handayani, Murniati. 2015. Analisis Argumentasi Siswa Kelas X SMA Muhammadiyah 1 Palembang dengan Menggunakan Model Argumentasi Toulmin. Jurnal Inovasi Dan Pembelajaran 2(1), 60-68.

Keraf, G. 2007. Argumentasi dan Narasi. Jakarta: PT Gramedia Pustaka Utama.

Llewellyn. 2013. Teaching High Scholl Science Through Inquiry and Argumentation. USA: Corwin.

Mazfufah,N.F. 2017. Pengaruh metode Diskusi Isu-Isu Sosiosaintifik Terhadap Kemampuan Penalaran IImiah Siswa. (Online) http// pascaundikhsa.ac.id / index.jurnal. diakses pada 30 Januari 2019.

McNeill, K.L. 2011. Elementary Student's Views of Explanation, Arrgumentation, Evidence, and Their Abilities to Construct Arguments Over The School Year. Journal of Research in Science Teaching, 48(7): 793-823.

Newton, Driver, R, \& Osborne, J. 2000. Establishing The Norms of Scientific Argumentation In Classrooms. Science Education, 84(1): 287-312.

Osborne, J. K. Boesma, M. Goedhart, O. De Jong, \& H. Eijkehof. 2005. The Role of Argument in Developing Science Literacy'. Research and Quality of Science Education. Dordrecht, Nederlands: Spinger. 
Ratchlif. 2003. Teaching for Understanding of Science Contexts Sosiosaintifik Issue: Evidence from Century science courses. Journal of research.46(8): 945-959.

Sadler, T. D. 2011. Socio-Scientific Issues in The Classroom: Teaching, Learning And Research. New York: Springer.

Sandoval. 2005. The Quality of Students Use Evidence in Writen Scientific Explanation Cognition And Intruction. Journal International Of Science Education. 23(1) :23-25.

Sondang, R. 2012. Identifikasi Keterampilan Argumentasi Melalui Analisis "Toulmin Argumentation Pattern (TAP)" pada Topik Kinematika bagi Mahasiswa Calon Guru. Medan: Universitas Negeri Medan.

Song, Y., \& Deane, P. 2014. A Case Study in Principled Assessment Design: Designing Assessments to Measure And Support The Development of Argumentative Reading and Writing Skills. Psicologia Educativa. 20(2):99-108.

Yuliastini, I.B, Rahayu, S. \& Fajaroh, F. 2016. POGIL Berkonteks Socio Sciencetific Issus (SSI) dan Literasi Kimia Peserta Didik SMK. Prosiding. Semnas Pendidikan IPA Pascasarjana UM. Vol.1:Malang.

Zeidler, D. L., \& Nichols, B. H. 2009. Socioscientific Issues: Theory and Practice. Journal of Elementary Science Education, 21(2), 49-58.

Zeidler,D.L, Sadler, T.D., Simmons, M. L., \& Howes,E. V. 2002. Beyond STS: A ResearchBaseframework for Socioscientific Issues Education. Science Education, 89(3). 